UNIVERSIDADE DE SÃO PAULO

FACULDADE DE MEDICINA VETERINARIA -- DEPARTAMENTO DE QUIMICA

ORGÃNICA E BIOLÓGICA

Diretor: Prof. Dr. Fonseca Ribeiro

FACULDADE DE HIGIENE E SAÚDF PÚBLICA - DEPARTAMENTO DE NUTRIÇAO

Diretor: Prof. Dr. Francisco A. Cardoso

\title{
PROTECTIVE ACTION OF OXALIC ACID IN RELATION TO ASCORBIC ACID AGAINST ITS OXIDATION BY. THE ASCORBIC ACID OXIDASE *
}

Fonseca RiBsiro

3 graphics on the text
F. A. Cardoso

In a previous paper (Fonsica Ruberro \& Cardoso, 1950) in which. we demonstrated the anti-oxidative action of the oxalic acid in relation to adrenalin, we also suggesled the possibility that the addition of oxalic acid to solutions of iron or copper acted by making the ionization of the salts of these metals diflicult. For this reason there was presented a hypothesis that oxidative processes, catalyzed by the ions of iron or copper, should be inhibited or delayed by oxalic acid. In fact, we verified in the above mentioned paper that the addition of oxalic acid to the solution of ascorbic acid makes them more stable. In consequence, it should be reasonable to admit that oxalic acid acting by the formation of a weak dissociable combination with copper or iron present in the oxidalive system could also act in those processes, due to enzymes having an active group formed by copper or iron. To verify this hypothesis experimentally we decided to study the action of oxalic acid in the oxidative process due to the ascorbic acid oxidase for this enzyme belongs to those having copper in their active group. A supporting reason for the choice of this material for our study was the possibility of finding an explanation to the well known fact of the existence in animal or vegetable materials of substances, not yet identified, which protect ascorbic acid against the oxidation by the ascorbic acid oxidase (BARRON, Barjon \& Klimplerer, 1936 and Pimenta, 1941).

Indeed, the experiments we undertook confirmed the suggested hypothesis of the existence of a definite protective action of oxalic acid in relation to ascorbic

\footnotetext{
* Presented to the 1st. International Congress of Biochemistry, Cambridge, 1949.
} 
acid in its qxidation by the ascorbic acid oxidase. We will now present those experimental results as well as those related to the behaviour of oxalic acid in the oxidation of ascorbic acid by the sole presence of the copper ion and its comparison with the similar action exerted by thiourea in the oxidation of ascorbic acid by copper, which was demonstrated by Huej.in \& Myee Stephens (1948).

\section{EXPERIMENTAL}

The solutions of ascorbic acid we used were always prepared at the time of the experiment and titrated by Tillmans reagent.

We used, for the oxidative action, the ascorbic acid oxidase, prepared from cucumbers (Cucumis sativus) following the technic of Fujrta \& Sakamoto (1938) slightly modified by Leser (1941). The enzyme was previously titrated by the method of Talber \& KLEINER (1935). The action of the ascorbic acid oxidase on the ascorbic acid in all the experiments was standardized to the time of 15 minutes and to the temperature of $40^{\circ} \mathrm{C}$, in a water bath, thus fulfilling the most favorable conditions for enzymatic action.

We found it convenient to work with the quantity which, at the already mentioned time and temperature, promoted the oxidation of about $50 \%$ of the initial ascorbic acid. The quantity of one tenth of a $\mathrm{ml}$ of the stock solution was the indicated one for quantities of ascorbic acid near $0.2 \mathrm{mg}$ per $\mathrm{ml}$.

The enzymatic action was always inhibited, after the desired time, by the addition to each test tube of $2 \mathrm{ml}$ of a 10 per cent solution of metaphosphoric acid.

To stabilize the $\mathrm{pH}$ during the experiments we always used buffers of disodium phosphate and citric acid according to McIlvaine (in CLark, 1928). Buffers' efficiency was potentiometrically controlled.

\section{INFLUENCE OF $\mathrm{pH}$}

In preliminary tests we verified that the protective action of oxalic acid was influenced by the $\mathrm{pH}$ of the medium. We decided then to determine what variation in the intensity of this action would result from varying the $\mathrm{pH}$ value. For this, using the same amounts of ascorbic acid and oxalic acid we varied the $\mathrm{pH}$ from 3.5 to 6.0 .

We obtained the following results. 
TABLE 1

INFLUENCE OF $\mathrm{pH}^{\circ}$ ON THE PROTECTIVE ACTION OF OXALIC ACID IN RELATION TO ASCORBIC ACID, IN ITS OXIDATION BY THE ASCORBIC ACID OXIDASE

Ascorbic acid (initial) $1 \mathrm{ml}=0.204 \mathrm{mg}$ (in each tube)

Ascorbic acid oxidase $0.1 \mathrm{ml}$ of the stock soiution (in each tube)

Temperature: $40^{\circ} \mathrm{C}$-- Time: $15^{\prime}$ - After this time $\mathrm{HPO}_{3}$, was added to each tube - $2 \mathrm{ml}$ of a $10 \%(\mathrm{w} / \mathrm{v})$ solution

\begin{tabular}{c|c|c|c}
\hline Tube n.o & Oxalic acid & $\begin{array}{c}\text { Phosphoric-citric } \\
\text { buffer }(5 \mathrm{ml}) \mathrm{pH}\end{array}$ & $\begin{array}{c}\text { Ascorbic acid } \\
\text { (residual) }\end{array}$ \\
\hline 1 & $1 \mathrm{mg}$ & 3.5 & 0.206 \\
2 & $1 \mathrm{mg}$ & 3.5 & 0.195 \\
3 & $\cdots$ & 4.0 & 0.202 \\
4 & $1 \mathrm{mg}$ & 4.0 & 0.174 \\
5 & - & 4.5 & 0.188 \\
6 & $1 \mathrm{mg}$ & 4.5 & 0.102 \\
7 & - & 5.0 & 0.055 \\
8 & $1 \mathrm{mg}$ & 5.0 & 0.007 \\
9 & - & 5.5 & 0.007 \\
10 & $1 \mathrm{mg}$ & 5.5 & $\mathrm{Nil}$ \\
11 & - & 6.0 & $\mathrm{Nil}$ \\
12 & & 6.0 & $\mathrm{Nil}$ \\
\hline
\end{tabular}

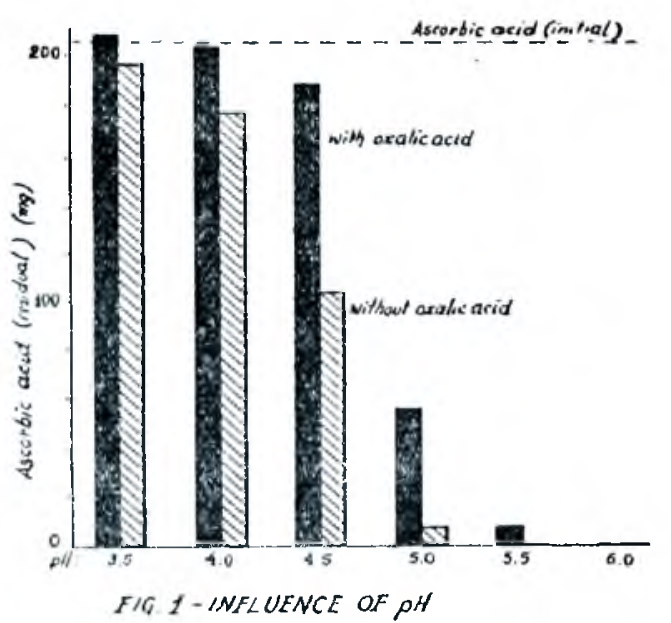

As can be seen by these results the protective action of oxalic acid was more evident at $\mathrm{pH} 4.5$ and at this same $\mathrm{pH}$ ascorbic acid oxidase alone acted 
satisfactorily. For that reason we began to use $\mathrm{pH} 4.5$ systematically in the following experiments.

Having established this preliminary we proceeded to make the quantitative study of the protective action of oxalic acid; for this purpose we made a series of experiments of which the following one (Table 2, represented by Fig. 2) is quite representative.

TABLE 2

PROTECTIVE ACTION OF OXALIC ACID IN RELATION TO ASCORBIC ACID IN THE PRESENCE OF ASCORBIC ACID OXIDASE. VARIATION IN RELATION TO THE AMOUNTS OF OXALIC ACID

Ascorbic acid (initial) $1 \mathrm{ml}=0.2 \mathrm{mg}$ (in each tube)

Buffer $\mathrm{pH} 4.5-5 \mathrm{ml}$ (in each tube)

Temperature: $40^{\circ} \mathrm{C}$ - Time: 15' - After this time 3 IPO $_{3}$ was added to each tube $-2 \mathrm{ml}$ of a $10 \%(\mathrm{w} / \mathrm{v})$ solution

\begin{tabular}{|c|c|c|c|}
\hline Tube n.o & Oxalic acid mg & $\begin{array}{l}\text { Ascorbic acid } \\
\text { oxidase }\end{array}$ & $\begin{array}{l}\text { Ascorbic acid } \\
\text { (residual) } \mathrm{mg}\end{array}$ \\
\hline 1 & - & - & 0.195 \\
\hline 2 & 一 & 0.1 & 0.103 \\
\hline 3 & 0.01 & 0.1 & 0.107 \\
\hline 4 & 0.01 & 0.1 & 0.108 \\
\hline 5 & 0.02 & 0.1 & 0.110 \\
\hline 6 & 0.02 & 0.1 & 0109 \\
\hline 7 & 0.04 & 0.1 & 0.119 \\
\hline 8 & 0.04 & 0.1 & 0.119 \\
\hline 9 & 0.06 & 0.1 & 0.128 \\
\hline 10 & 0.06 & 0.1 & 0.128 \\
\hline 11 & 0.08 & 0.1 & 0.135 \\
\hline 12 & 0.08 & 0.1 & 0.135 \\
\hline 13 & 0.10 & 0.1 & 0.138 \\
\hline 14 & 0.10 & 0.1 & 0.138 \\
\hline 15 & 0.15 & 0.1 & 0.148 \\
\hline 16 & 0.15 & 0.1 & 0.148 \\
\hline 17 & 0.20 & 0.1 & 0.152 \\
\hline 18 & 0.20 & 0.1 & 0.152 \\
\hline 19 & 0.40 & 0.1 & 0.169 \\
\hline 20 & 0.40 & 0.1 & 0.168 \\
\hline 21 & 0.60 & 0.1 & 0.175 \\
\hline 22 & 0.60 & 0.1 & 0.175 \\
\hline 23 & 0.80 & 0.1 & 0.180 \\
\hline 24 & 0.80 & $0 . \overline{1}$ & 0.181 \\
\hline 25 & 1.00 & 0.1 & 0.184 \\
\hline 26 & 1.00 & 0.1 & 0.186 \\
\hline 27 & 1.50 & 0.1 & 0.188 \\
\hline 28 & 1.50 & 0.1 & 0.189 \\
\hline 29 & 2.00 & 0.1 & 0.193 \\
\hline 30 & 2.00 & 0.1 & 0.194 \\
\hline
\end{tabular}




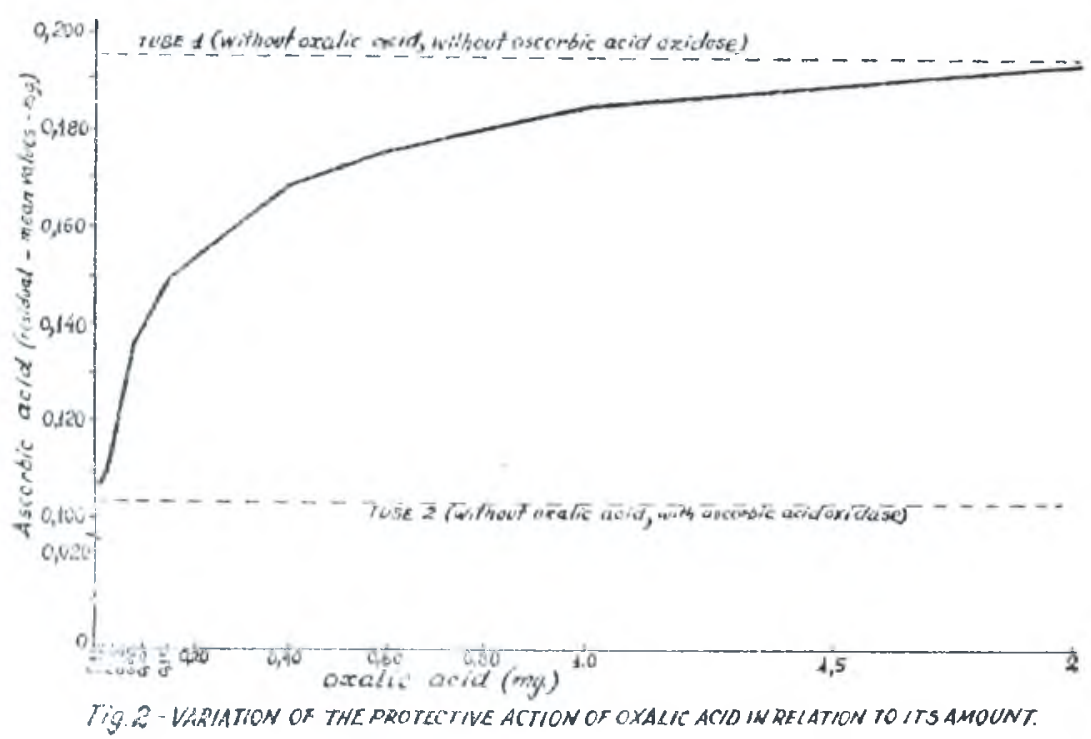

Trying 10 adapt a curve to the obtained data we started from the consideration that the curve should have a superior asymptote $\mathrm{K}=1950$. After a series of interpolatory attempts we obtained as a most adaptable curve a modified exponential (Compertz' type) having as its equation:

$$
\mathrm{y}=1950-715.47 \times 0.98142^{\mathrm{x}}
$$

The development of the interpolated curve presents, initially, ordinate values greater than the observed ones; at the intermediary phase it presents lesser values, giving. afterwards a very good adaptation. The mean of the differences, taken as absolute values, represent $3.63 \%$ of the mean of the values of $y$.

Having demonstrated the protective action of the oxalic acid in relation to ascorbic acid against its oxidation by the ascorbic acid oxidase which is an enzyme containing copper as ils action group, it seemed to us that the comparative study of the action of the cupric ion as oxalate and that of another salt would be timely. For this purpose we selected copper sulphate.

The following experimonts (Table 3) shows the results which were obtained (they are also represented by Fig. 3). 
TABLE 3

COMPARISON BETWEEN THE OXIDATIVE ACTION OF CUSO, AND THAT OF $\mathrm{Cu}(\mathrm{COO})_{2}$ IN RELATION TO ASCORBIC ACID

Ascorbic acid (initial) $1 \mathrm{ml}=0.234 \mathrm{mg}$ (in each tube)

Buffer $\mathrm{pH} 4.5-1 \mathrm{ml}$ (in each tube)

Temperature: $40^{\circ} \mathrm{C}$ - Time: 15' - After this time IIPO, was added to each tube $-2 \mathrm{ml}$ of a $10 \%(\mathrm{w} / \mathrm{v})$ solution

\begin{tabular}{|c|c|c|c|}
\hline Tube n.o & $\begin{array}{l}\text { CuSO } \\
\text { (Cu "in" } \mu g)\end{array}$ & $\begin{array}{c}\mathrm{Cu}(\mathrm{COO})_{2} \\
(\mathrm{Cu} \text { "in" } \mu \mathrm{g})\end{array}$ & $\begin{array}{l}\text { Ascorbic acid } \\
\text { (residual) } \mathbf{m g}\end{array}$ \\
\hline 1 & - & - & 0.220 \\
\hline 2 & 1 & - & 0.161 \\
\hline 3 & - & 1 & 0.217 \\
\hline 4 & 2 & - & 0.138 \\
\hline 5 & 一 & 2 & 0.208 \\
\hline 6 & 3 & 一 & 0.129 \\
\hline 7 & - & 3 & 0.208 \\
\hline 8 & 4 & - & 0.121 \\
\hline 9 & - & 4 & 0.204 \\
\hline 10 & 5 & - & 0.116 \\
\hline 11 & 一 & 5 & 0.205 \\
\hline 12 & 6 & - & 0.115 \\
\hline 13 & - & 6 & 0.202 \\
\hline 14 & 7 & 一 & 0.111 \\
\hline 15 & - & 7 & 0.202 \\
\hline 16 & 8 & - & 0.108 \\
\hline 17 & - & 8 & 0.195 \\
\hline 18 & 9 & - & 0.108 \\
\hline 19 & - & 9 & 0.198 \\
\hline 20 & 10 & - & 0.107 \\
\hline 21 & - & 10 & 0.196 \\
\hline
\end{tabular}

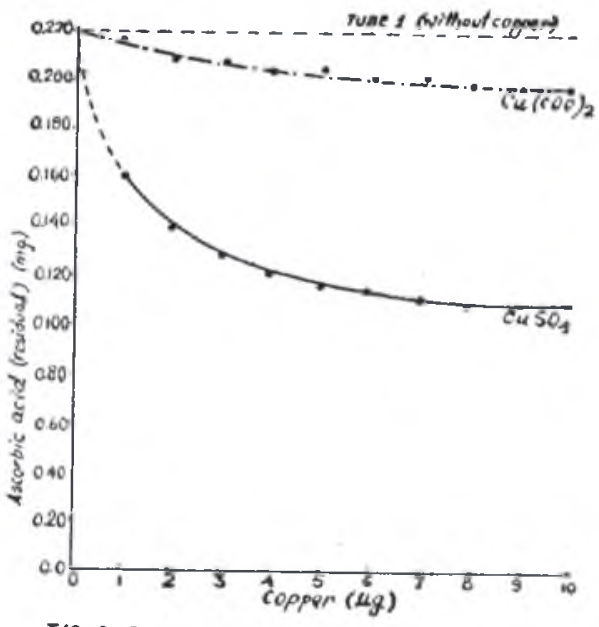

7/6. 3- COMOARISON BETWE EN THE OXIOATINE ACTION OF COS ANO THAT OF CA (COO) 2 WN REATION TO AOCORBICACIA 
In this way we confirmed the results obtained by Huelin \& Myee Stephens (1948), who, in pure solutions, observed a good protection with oxalic acid in relation to ascorbic acid in its copper catalyzed oxidation. These authors also verified that thiourea presented a prominent protective action against the copper catalyzed ascorbic acid oxidation, in pure solutions. With the purpose of verifying whether thiourea possessed the same protective power against the oxidation by the ascorbic acid oxidase and to compare its action with that of oxalic acid we proceeded to the experiment reported below.

TABLE 4

COMPARATIVE STUDY OF THE ACTION OF OXALIC ACID AND OF THIOUREA IN THE OXIDATION OF ASCORBIC ACID BY COPPER AND BY THE ASCORBIC ACID OXIDASE

Ascorbic acid (initial) $1 \mathrm{mI}=0.206 \mathrm{mg}$ (in each tube)

Buffer pH 4.5 - $5 \mathrm{ml}$ (in each tube)

Temperature: $40^{\circ} \mathrm{C}$ - Time: $1^{\prime}$ - After this time $\mathrm{HPO}_{2}$ was added to each tube $-2 \mathrm{ml}$ of a $10 \%(\mathrm{w} / \mathrm{v})$ solution

\begin{tabular}{|c|c|c|c|c|c|}
\hline Tube n.o & $\begin{array}{c}\mathrm{CuSO}_{4} \\
(\mathrm{Cu} \text { in } \mu \mathrm{g})\end{array}$ & $\begin{array}{c}\text { Oxalic acid } \\
\mathrm{mg}\end{array}$ & $\begin{array}{c}\text { Thiourea } \\
\text { mg }\end{array}$ & $\begin{array}{l}\text { Ascorbic } \\
\text { acid } \\
\text { oxidase }\end{array}$ & $\begin{array}{c}\text { Ascorbic acid } \\
\text { (residual) } \\
\text { mg }\end{array}$ \\
\hline 1 & - & - & - & - & 0.197 \\
\hline 2 & 10 & 一 & - & - & 0.118 \\
\hline 3 & 10 & 1.0 & - & - & 0.165 \\
\hline 4 & 10 & - & 1.0 & 一 & 0.140 \\
\hline 5 & - & - & - & 0.1 & 0.106 \\
\hline 6 & - & 0.5 & - & 0.1 & 0.167 \\
\hline 7 & - & 1.0 & - & 0.1 & 0.174 \\
\hline 8 & - & 2.0 & - & 0.1 & 0.183 \\
\hline 9 & $\longrightarrow$ & - & 0.5 & 0.1 & 0.100 \\
\hline 10 & $\longrightarrow$ & 一 & 1.0 & 0.1 & 0.097 \\
\hline 11 & - & - & 2.0 & 0.1 & 0.108 \\
\hline
\end{tabular}

By the above given results we can verify that in the oxidation of ascorbic acid by copper, thiourea in spite of its definite protective action was less efficient than an equal quantity of oxalic acid under the conditions of our experiments. Hueirin \& Myee Stephens (1948), working in different conditions, found that the protective action of thiourea was more efficient than that of oxalic acid.

On the other hand we can see that thiourea showed no protective action in relation to the oxidation by the ascorbic acid oxidase. 


\section{DISCUSSION}

There can be no doubt that oxalic acid in certain conditions of $\mathrm{pH}$ interferes with the activity of ascorbic acid oxidase on its specific substratum, ascorbic acid; such an interference corresponds to a decrease of the activity that the enzyme should have shown under the conditions of the experiment.

It can also be verified that the catalytic action of copper in the oxidation of ascorbic acid is partially inhibited by oxalic acid as well as by others substances such as thiourca as was verified by Huelin \& Myel Stephens (1948) and xanthine as observed by Giri \& Krishnamurthy (1941). Neverthelcss thiourea proved to be completely inactive against ascorbic acid oxidase as well as xanthine which also proved inactive as was pointed out by the research of Fonseca Rireiro \& Bonoldi (1943).

It is therefore evident that we cannot admit the same mechanism of action for thiourea and xanthine on one hand, and for oxalic acid on the other. The latter acts perhaps by its capacity of reacting with copper to form a weak dissociable combination even in the case in which the metal constitutes the action group of an enzyme like ascorbic acid oxidase; of course we should admit here the possibility of a complex through which the enzyme would lack the cupric ion indispensable to its action.

The evident action of oxalic acid in the protection of ascorbic acid in the presence of ascorbic acid oxidase enables us to suggest its possible protective role in many animal or vegetable substrata in which the existence of substances inhibiting ascorbic acid oxidase was demonstrated long ago. Really the existence of oxalic acid in many animal or vegetable tissues may be suggested but the fact that its importance has been considered as secondary until now disencouraged its systematic detection except when its presence revealed itself by relalively great quantities. In spite of this point of view, it has been observed (Fonseca Ribeiro \& Cardoso, 1950) that oxalic acid protects adrenalin, tyrosin, and other substances against the copper catalyzed oxidation besides protecting ascorbic acid against the specific action of ascorbic acid oxjdase. These observations and the possibility of other copper or iron containing enzymes being influenced in their activity by oxalic acid seem to be such as to confer on it a more significant role in the interpretation of vital phenomena, in the future.

\section{SUMIMARY}

1. Oxalic acid has a definite protective action on ascorbic acid in its oxidation by ascorbic acid oxidase, an enzyme whose active group contains copper; this action is best revealed at $\mathrm{pH} 4.5$. 
2. Oxalic acid exerts also its protective action on ascorbic acid oxidation by copper; the comparison between the oxidative effect of copper oxalate and that of copper sulphate shows that the latter is much more intense.

3. The protective action of thiourea exerts itself in the oxidation by copper though less intensively than that of oxalic acid but it does not reveal itself in the oxidation by ascorbic acid oxidase.

4. The protective action of oxalic acid in the oxidation of ascorbic acid by the ascorbic acid oxidase suggests a new field of investigation in the branch of knowledge of those substances, not identified up to the present, which, in natural substrata, protect the ascorbic acid against such an oxidation.

\section{REFERENCES}

Barron, E. S. G. - Banron, $\Lambda$. G. \& Kiemperer, F. - 1930 - J. Biol. Chem., 116: 563-73

CuAnk, W. M. -- 1928 -- The determination of hydrogen ions. 3rd ed. Baltimore, Williams and Wilkins Company

Fongec. Riberim, D. da \& Brixom, V. 1913 - Rev. Fac. Med. Vet., S. Paulo, 2(3): 87-97

Fongeca Rinemo, D. na \& Cahdosn. F. A. - 1950 - Rev. Fac. Med. Vet., S. Paulo, 4(2) $235-40$

Fujita, A. \& Sakamoto, T. -- 1938 - Biochem. Ztschr., 297:10-23

Girt, K. V. \& Kriginaminthy, P. V. - 1941 - Nature, London, 147:59

Huet,in. F. E. \& Myee Stephens, I. - 1948 - Aust. J. Sci. Res., 1:50-7,

Leser, W. S. P. - 1941 - Da importância na higiene alimentar em nossa população, do suprimento de vitamina C pela "Musa chinensis", Sweet (banana nanica), e "Musa paradisiaca", L. sub-espécie "sapientum" Schum., variedade maçã (banana maçã). Tese. São Paulo

Pinenta, N. - 1941 - Da proteção do ácido ascórbico observada em dosagens pelo método enzimático. Fxperimentação na manga ("Mangifera indica", L.). 'Tese. São P'aulo

Taubek, II. \& Ki.tiner, I. S. -- 1935 - Proc. Soc. Exp. Biol. \& Med., 32:577-8

We here thank Dr. 1'. Egydio de Carvalho, professor of Biostatistics, University of São Paulo, Brazil, for giving us the interpolation of the curve. 